\title{
Effects of additional colostrum feeding on the levels of protein fractions in calves' serum
}

\author{
Edyta Wojtas ${ }^{1 *}$, Marta Iwaszkiewicz' ${ }^{1}$ Andrzej Zachwieja', \\ Ewa Pecka-Kietb², Katarzyna Paczyńska', Joanna Tumanowicz'
}

\begin{abstract}
'Wroclaw University of Environmental and Life Sciences, Department of Cattle Breeding and Milk Production, Chełmońskiego 38c, 51-630 Wroclaw, Poland

${ }^{2}$ Wroclaw University of Environmental and Life Sciences, Department of Biostructure and Animal Physiology, Norwida 31, 50-375 Wroclaw, Poland

*Corresponding author: E-mail: edyta.wojtas@upwr.edu.pl
\end{abstract}

\section{Abstract}

The aim of this study was to investigate the impact of additional colostrum feeding to new born calves on levels of selected serum protein fractions. The study was conducted on a commercial dairy farm. Twenty-four cows of Polish Holstein-Friesian breed and their calves were included in the trial. Chemical composition, the somatic cell count (SCC), the total bacteria count (TBC) and immunoglobulin G (IgG) concentration were determined in colostrum samples. Blood was collected via jugular vein puncture from a total of 24 calves at the $36^{\text {th }}$ hour of life. Total serum protein (TSP), as well as its fractions (albumins, globulins) and IgG concentration were determined. Greater IgG, total protein, albumins and globulins concentrations were found in serum of calves fed colostrum four times compared with three times on the first day of life. It was concluded that increasing the number of colostrum feedings to four times can be beneficial to forming of passive immunity of newborn calves.

Key words: feeding, colostrum, calves, protein fractions, serum

\section{Introduction}

Due to the multilayer structure of the placenta in cattle, the calves are born devoid of any significant resistance to diseases (Amaral-Phillips et al., 2014). Therefore, ingestion and absorption of colostral immunoglobulins is the most effective way to obtain protection against pathogens. Unfortunately, the lining of the small intestine in calves after birth undergoes a rapid maturing process, including intestinal cell turnover, increasing abo- masal acidity, development of intestinal secretions and appearance of intra-epithelial digestive vacuoles (Quigley, 2004). It means that efficiency of colostrum immunoglobulin absorption is decreasing with every hour after birth. The high extent of absorption is observed within the first 2-6 hours after birth (Conneely et al., 2014) and then it rapidly reduces to $11.5 \%$ at $24 \mathrm{~h}$ post-calving (Matte et al., 1982). Consequently, the early feeding of colostrum ensures the highest level of passive immunity. Quantity and quality of colostrum are also 
important factors. Immediately after birth, the calf should receive 3 to 4 litres of high-quality colostrum (IgG concentrations > $50 \mathrm{mg} / \mathrm{mL}$ ) (McGuirk and Collins, 2004). However, the administration of excessive colostrum relative to birth weight can extend the wall of abomasum leading to diarrhea and therefore a decrease in immunoglobulin $\mathrm{G}$ absorption (Mokhber-Dezfooli et al., 2012). Evidence indicates a beneficial rearing result with feeding of colostrum with a high antibody concentration (84 $\mathrm{mg} / \mathrm{mL}$ ), 2 litres in the first feeding and 2 litres at 12 hour of life, compared with feeding 4 litres of colostrum after birth (Jaster, 2005). This confirms the theory that in the first feeding the calf should acquire about 150-200 g of IgG (Lago et al., 2018).

The increase in the incidence of diseases in calves during the first 3-4 weeks of life, is the result of improper colostrum feeding (Rocha et al., 2012; Raboisson et al., 2016). Therefore, the main objective of this study was to investigate the impact of additional colostrum feeding to newborn calves on selected serum protein fraction levels.

\section{Materials and methods}

\section{Animals housing and management}

The study was conducted on a commercial dairy farm (herd of 200 cows). The average milk yield per cow during 305-day lactation period was $8,500 \mathrm{~kg}$. Twenty-four cows of Polish Holstein-Friesian breed and their heifer calves were included in the analysis. During the experiment cows were kept in calving boxes prior to calving (free-stall system) and fed with total mixed ration (TMR) system. The feed ration consisted of maize silage, grass silage, maize grain silage, sugar beet pulp silage, barley grain and soybean meal (CP $16.3 \%$ DM, NDF $34.5 \%$ DM, ADF $22.3 \%$ DM). Cows were selected on the basis of parity (between $2^{\text {nd }}$ and $4^{\text {th }}$ parity), calving ease (non-assisted) and health status (free of metabolic disorders and mastitis). In order to provide colostrum to a newborn calf on time, all parturitions were monitored by a video camera. Cows were milked immediately after parturition. The colostrum from the first milking after calving was kept in the milking container and placed into a cooling room at approximately $4{ }^{\circ} \mathrm{C}$. Colostrum quality was checked using a digital Brix refractometer. It is assumed that values above $21 \%$ indicate a colostrum with IgG concentration of $50 \mathrm{mg} / \mathrm{mL}$ or higher (Quigley et al., 2013) and can be used for the calf's first feed. Before the feeding, the colostrum was slowly warmed up to $37-40{ }^{\circ} \mathrm{C}$ before it was given to each calf by a nipple bottle. Each calf obtained the colostrum of their own mother. All calves were fed high quality colostrum (above $21 \%$ Brix) obtained at the first milking after calving. In the control group $(n=12)$ colostrum was given three times, and in the experimental group $(n=12)$ four times on the first day of life. The first feeding of colostrum was within 1 hour after birth and another in every six hours. The mean birth weight of calves from control group was $38 \mathrm{~kg}$ and calves from experimental group - 36 $\mathrm{kg}$. Therefore, at every feeding colostrum were given in amount of 2 liters that made up $5 \%$ of body weight (Aydogdu et al., 2018).

\section{Samples collection and analysis}

$250 \mathrm{~mL}$ of colostrum was collected from each cow and was immediately frozen at $-20{ }^{\circ} \mathrm{C}$. Once thawed, the levels of dry matter, protein, fat and lactose (Infrared Analyser 150 Bentley), as well as somatic cell count (SCC; Somacount Analyser 150 Bentley), total bacteria count (TBC; Bactocount Analyser 70 Bentley) and IgG concentration (polyacrylamide gel electrophoresis) were determined. The blood of all calves was taken at the $36^{\text {th }}$ hour of life, in the amount of $10 \mathrm{~mL}$ from the external jugular vein. Immediately after collection blood samples were centrifuged for 5 min at $3000 \mathrm{~g}$, at $19^{\circ} \mathrm{C}$ (MPW 350R High Speed Brushless (entrifuge), in order to obtain the serum. The total protein, its fractions (by Pentra 400 Horiba ABX Diagnostics using reagents from $A B X$ ) and the level of IgG (by ELISA using reagents from Bethyl) were determined in all blood samples.

\section{Statistical analysis}

Data were subjected to one-way analysis of variance (ANOVA), using STATISTICA Version 10.0. (StatSoft, USA). The significance of differences between groups was evaluated using the Duncan test. 


\section{Results and discussion}

There were no significant differences in the colostrum composition of cows between groups within herd (Table 1), and the levels of analysed components were in the range of results obtained by other authors (Zachwieja et al., 2002; Nowak et al., 2012; Wojtas and Zachwieja, 2016).

TABLE 1. Mean ( \pm SD) content of the chemical composition, somatic cell counts (SCC) and total bacteria counts (TBC) in colostrum of cows

\begin{tabular}{l|r|r}
\hline Components & Group I & Group II \\
\hline Dry matter (\%) & $21.34 \pm 2.89$ & $22.08 \pm 3.01$ \\
\hline Fat $(\%)$ & $5.38 \pm 2.23$ & $6.17 \pm 2.61$ \\
\hline Lactose $(\%)$ & $1.96 \pm 0.49$ & $2.12 \pm 0.51$ \\
\hline Protein $(\%)$ & $12.85 \pm 2.45$ & $12.59 \pm 2.39$ \\
\hline Urea $(\mathrm{mg} / \mathrm{L})$ & $180.55 \pm 59.87$ & $191.03 \pm 72.22$ \\
\hline SCC $\left(\times 10^{3} / \mathrm{mL}^{-1}\right)$ & $191.33 \pm 68.21$ & $221.90 \pm 101.12$ \\
\hline TBC $\left(\right.$ cells $\left./ \mathrm{mL}^{\prime}\right)$ & $203.51 \pm 179.63$ & $301.24 \pm 235.04$ \\
\hline
\end{tabular}

I - control group; II - experimental group

SCC - somatic cell count; TBC - total bacteria count

Table 2 shows the IgG concentration in colostrum of cows and in serum of calves at the $36^{\text {th }}$ hour of life. Although, the cows from group I produced colostrum of higher IgG concentration compared to cows from group II, higher levels of IgG were observed in serum of calves from group $\|(p<0.05)$. These results suggest that application of additional feeding of colostrum in calves during the first hours of life lead to an increase in the efficiency of immunoglobulin absorption in the small intestine. In turn, the calf's acquisition of colostral immunoglobulins through absorption from the intestine into the circulation is equivalent to achieving passive transfer of immunity (Singh et al., 2011). In addition to the number of feeding of colostrum, the volume is one of the critical factors determining serum IgG concentration. Contrary to studies Faber et al., (2005) and Kaske et al., (2005) who reported beneficial effects from applying 4 litres of colostrum in calves immediately at birth, in our study all calves fed of high-quality colostrum in amount of 2 litres (first feeding) received the high serum IgG levels at the $36^{\text {th }}$ hour of life, which exceeded the suggested value (15 g/L) by far. It seems that if colostrum has a high content of IgG, it can be used in amount of 2 litres for the calf's first feed in order to obtain passive transfer of immunity. This theory is consistent with the results of Jaster (2005) and Sakai et al., (2012). Lower IgG concentration in serum of calves was obtained in the research by Nowak et al. (2005).

TABLE 2. Mean $( \pm \mathrm{SD})$ immunoglobulin $\mathrm{G}$ concentrations $(\mathrm{g} / \mathrm{L})$ in the first colostrum of cows and in the serum of calves at the $36^{\text {th }}$ hour of life

\begin{tabular}{l|r|r}
\hline \multirow{2}{*}{ Colostrum } & Group I & IgG concentration \\
\cline { 2 - 3 } & $77.65 \pm 6.28$ & $73.29 \pm 5.92$ \\
\hline Serum & $28.35^{\mathrm{b}} \pm 5.58$ & $32.21^{\mathrm{a}} \pm 4.13$ \\
\hline
\end{tabular}

I - control group; II - experimental group

$a, b$ - differences between groups $p<0.05$

In the serum of all tested calves, total protein, albumin and globulin concentration were consistent with the results of other authors (Šlosárková et al., 2014; Tóthová et al., 2016). The highest values of these protein fractions were observed in calves from the experimental group (Table 3), which may indicate a beneficial effect of the application of a fourth additional colostrum feeding in the first hours of life. Importantly, in the case of total protein and globulins concentrations, observed differences were statistically significant $(p<0.01)$. These results are consistent with the findings of Nussbaum et al., (2002) and Rocha et al., (2012). According to these authors, intake of a good quality colostrum results in significantly increased concentrations of the total protein and globulin concentrations in serum of neonatal calves.

The most frequently used method to assess the passive transfer of immunity in calves is to determine the level of immunoglobulins in serum between 24 and 48 hours after birth. In this study, the other protein fractions-albumin and globulins-were also taken into account. Based on this fact, we found that the high total protein content in serum of calves was associated to the high level of IgG. According to Wilm et al., (2018) and Marc et al., (2018) this relationship indicates that measurement of IgG or TSP concentrations may provide reliable results regarding the passive transfer of immunity in newborn calves. 
TABLE 3. Mean $( \pm \mathrm{SD})$ serum protein fraction levels $(\mathrm{g} / \mathrm{L})$ at the $36^{\text {th }}$ hour of life in calves fed colostrum three and four times during first day of life

\begin{tabular}{l|r|r}
\hline Protein fractions & Group I & Group II \\
\hline Total protein & $62.50^{\mathrm{B}} \pm 6.27$ & $71.61^{\mathrm{A}} \pm 5.99$ \\
\hline Albumins & $23.65 \pm 4.21$ & $25.46 \pm 3.38$ \\
\hline Globulins & $38.73^{\mathrm{B}} \pm 4.84$ & $44.09^{\mathrm{A}} \pm 5.52$ \\
\hline
\end{tabular}

| - control group; || - experimental group

$\mathrm{A}, \mathrm{B}$ - differences between groups $\mathrm{p}<0.01$

\section{Conclusions}

In order to obtain high level passive immunity, calves should receive good quality colostrum within the first two hours of life. With regards to the results obtained, it could also be concluded that increasing frequency of colostrum feeding in calves during the first day of life might increase the concentration of $\lg G$ and other protein fractions in serum.

\section{Učinci dodatnog hranjenja teladi kolostrumom na koncentracije proteinskih frakcija u krvnom serumu}

\section{Sažetak}

Cilj ove studije bio je istražiti utjecaj dodatnog hranjenja novorođene teladi kolostrumom u prvim satima života na odabrane razine proteinskih frakcija u serumu. Studija je provedena na komercijalnom gospodarstvu za proizvodnju mlijeka. Dvadeset i četiri krave poljskog holstein-frizijskog goveda i njihove teladi bili su uključeni u istraživanje. Osnovni sastav, broj somatskih stanica (BSS), ukupan broj bakterija (UBB) i koncentracija imunoglobulina G (IgG) određeni su u uzorcima kolostruma. Krv je uzeta punkcijom jugularne vene od ukupno 24 teleta drugog dana života. Određeni su ukupni proteini u serumu, njihove frakcije (albumini, globulini) i koncentracije IgG-a. U serumu teladi hranjene kolostrumom četiri puta određene su veće koncentracije IgG-a, ukupnih proteina, albumina i globulina u usporedbi s onima hranjenim tri puta prvog dana života. Zaključeno je kako povećanje broja hranjenja kolostrumom na četiri puta može biti korisno za stvaranje pasivnog imuniteta kod novorođene teladi.

\section{Ključne riječi: hranjenje, kolostrum, telad, frakcije proteina, serum}

\section{References}

1. Amaral-Phillips, D.M., Scharko, P.B., Johns, J.T., Franklin, S. (2014): Feeding and Managing baby calves from birth to three months of age. Agriculture and Natural Resources 1, $1-6$.

2. Aydogdu, U., Guzelbektes, H. (2018): Effect of colostrum composition on passive calf immunity in primiparous and multiparous dairy cows. Veterinarni Medicina 63 (1), 1-11. https://doi.org/10.17221/40/2017-vetmed

3. Conneely, M., Berry, D.P., Murphy, J.P., Lorenz, I., Doherty, M.L., Kennedy, E. (2014): Effect of feeding colostrum at different volumes and subsequent number of transition milk feeds on the serum immunoglobulin $G$ concentration and health status of dairy calves. Journal of Dairy Science 97 (11), 6991-7000. https://doi.org/10.3168/jds.2013-7494

4. Faber, S.N., Faber, N.E., Mccauley, T.C., Ax, R.L. (2005): Case study: effects of colostrum ingestion on lactational performance. The Professional Animal Scientist 21 (5), 420-425.

https://doi.org/10.15232/s1080-7446(15)31240-7
5. Jaster, E.H. (2005): Evaluation of quality, quantity and timing of colostrum feeding on immunoglobulin G1 absorption in Jersey calves. Journal of Dairy Science 88 (1), 296-302. https://doi.org/10.3168/jds.s0022-0302(05)72687-4

6. Kaske, M., Werner, A., Schuberth, H.J., Rehage, J., Kehler, W. (2005): Colostrum management in calves: effects of drenching vs. bottle feeding. Journal of Animal Physiology and Animal Nutrition 89 (3-6), 151-157. https://doi.org/10.1111/j.1439-0396.2005.00535.x

7. Lago, A., Socha, M., Geiger, A., Cook, D., Silva-del-Rio, N., Blanc, C., Quesnell, R., Leonardi, C. (2018): Efficacy of colostrum replacer versus maternal colostrum on immunological status, health, and growth of preweaned dairy calves. Journal of Dairy Science 101 (2), 1344-1354. https://doi.org/10.3168/jds.2017-13032

8. Marc, S., Kirovski, D., Mircu, C., Hutu, I., Otavă, G., Paul, C., Boldura, O.M., Tulcan, C. (2018): Serum Protein Electrophoretic Pattern in Neonatal Calves Treated with Clinoptilolite. Molecules 23 (6), 1278. https://doi.org/10.3390/molecules23061278 
9. Matte, J.J., Girard Seoane, J.R. (1982): Absorption of colostral immunoglobulin $\mathrm{G}$ in the newborn dairy calf. Journal of Dairy Science 65 (9), 1765-1770. https://doi.org/10.3168/jds.s0022-0302(82)82414-4

10. McGuirk, S.M., Collins, M. (2004): Managing the production, storage and delivery of colostrum. Veterinary Clinics of North America: Food Animal Practice 20 (3), 593-603. https://doi.org/10.1016/j.cvfa.2004.06.005

11. Mokhber-Dezfooli, M.R., Nouri, M., Rasekh, M., Constable, P.D. (2012): Effect of abomasal emptying rate on the apparent efficiency of colostral immunoglobulin G absorption in neonatal Holstein-Friesian calves. Journal of Dairy Science 95 (11), 6740-6749. https://doi.org/10.3168/jds.2012-5926

12. Nowak, W., Potkański, A., Zachwieja, A., Szulc, T., Wylegała, S., Werwińska, K. (2005): Effect of herb extracts on serum immunoglobulins and calf-rearing results. Medycyna Weterynaryjna 61 (9), 1049-1051.

13. Nowak, W., Mikuła, R., Kasprowicz-Potocka, M., Ignatowicz, M., Zachwieja, A., Paczyńska, K., Pecka, E. (2012): Effect of cow nutrition in the far-off period on colostrum quality and immune response of calves. Bulletin of the Veterinary Institute in Pulawy 56 (2), 241-246. https://doi.org/10.2478/v10213-012-0043-z

14. Nussbaum, A., Schiessler, G., Hammon, H.M., Blum, J.W. (2002): Growth performance and metabolic and endocrine traits in calves pair-fed by bucket or by automate starting in the neonatal period. Journal of Animal Science 80 (6), 1545-1555. https://doi.org/10.2527/2002.8061545x

15. Quigley, J.D. (2004): The role of oral immunoglobulins in systemic and intestinal immunity of neonatal calves. lowa State University, Ames, IA.

16. Quigley, J.D., Lago, A., Chapman, C., Erickson, P., Polo, J. (2013): Evaluation of the Brix refractometer to estimate immunoglobulin $\mathrm{G}$ concentration in bovine colostrum. Journal of Dairy Science 96 (2), 1148-1155. https://doi.org/10.3168/jds.2012-5823

17. Raboisson, D., Trillat, P., Cahuzac, C. (2016): Failure of passive immune transfer in calves: a meta-analysis on the consequences and assessment of the economic impact. PLoS One 11 (3), 1-19. https://doi.org/10.1371/journal.pone.0150452
18. Rocha, T.G., Nociti, R.P., Sampaio, A., Fagliari, J.J. (2012): Passive immunity transfer and serum constituents of crossbred calves. Brazilian Journal of Veterinary Research and Animal Science 32 (6), 515-522. https://doi.org/10.1590/s0100-736×2012000600008

19. Sakai, R.R., Coons, D.M., Chigerwe, M. (2012): Effect of single oroesophageal feeding of $3 L$ versus $4 L$ of colostrum on absorption of colostral IgG in Holstein bull calves. Livestock Science 148 (3), 296-299. https://doi.org/10.1016/j.livsci.2012.06.011

20. Singh, A.K., Pandita, S., Vaidya, M.M., Singh, S.V., Chandra., G., Pampoori, Z.A., Huozha, R., Pathan, M.M., Kushwaha, R., Sharma, V.K. (2011): Bovine colostrum and neonate immunity - a review. Agricultural Review 32 (2), 79-90.

21. Šlosárková, S., Fleischer, P., Pěnkava, O., Skřivánek, M. (2014): The assessment of colostral immunity in dairy calves based on serum biochemical indicators and their relationships. Acta Veterinaria Brno 83 (2), 151-156. https://doi.org/10.2754/avb201483020151

22. Tóthová, C., Nagy, O., Kováč, G., Nagyová, V. (2016): Changes in the concentrations of serum proteins in calves during the first month of life. Journal of Applied Animal Research 44 (1), 338-346. https://doi.org/10.1080/09712119.2015.1031791

23. Wilm, J., Costa, J.H.C., Neave, H.W., Weary, D.M., Keyserlingk, M.A.G. (2018): Technical note: Serum total protein and immunoglobulin G concentrations in neonatal dairy calves over the first 10 days of age. Journal of Dairy Science 101 (7), 6430-6436. https://doi.org/10.3168/jds.2017-13553

24. Wojtas, E., Zachwieja, A. (2016): The composition and physicochemical properties of colostrum in Black-andWhite Polish Holstein-Friesian cows, Montbéliarde cows and their Crossbreeds. Acta Scientiarum Polonorum Zootechnica 15 (2), 87-98. https://doi.org/10.21005/asp.2016.15.2.08

25. Zachwieja, A., Chrzanowska, J., Szulc, T., Dobicki, A. (2002): Immunoglobulin levels in the blood serum of calves in relation to physicochemical properties and trypsin inhibitory activity of the colostrum. Medycyna Weterynaryjna 58 (11), 874-876. 